\title{
MIT SPR spreads its wings in Volume II
}

\author{
Yana Petri ${ }^{1, *}$ \\ Edited by Grant A. Knappe and Friederike M. C. Benning
}

$\mathrm{n}$ the last two years, the science and policies surrounding COVID-19 vaccine development stood at the center of our lives, because they provided a clear escape route towards pre-pandemic normalcy. Now, from first-hand experience, we can fully grasp how critical it is for scientists, policymakers, and the public to communicate clearly, understand each other, and take collective action.

Our journal, MIT Science Policy Review (MIT SPR), provides a platform for initiating an open, jargon-free discussion between these three players. In Volume II, we reviewed a broad range of current issues at the intersection of science and policy. For example, in Seetharam et al., we suggested that quantum technology is likely to drive future innovation in cybersecurity, biology, and materials science and pointed out the need in training a multidisciplinary and adaptable future team of quantum scientists. In Bullock et al., we attracted attention to the rarely brought up issue of space debris, which threatens to destroy our space infrastructure and our global community through uncontrolled impact. We have also not shied away from discussing controversial topics such as mandatory vaccination against COVID-19, reducing open access publication costs for researchers, and encouraging the U.S. to take intentional action to retain more talented international scientists.

In addition to publishing review articles, MIT SPR has expanded this year to include an Interviews and a Perspectives section. The Interviews section of Volume II introduces readers to the life of prominent scientists-for instance, MIT Professor Emeritus Jonathan King-and their opinion on social responsibility and activism in academia. This year's Perspective section, which is a result of a fruitful collaboration with the Behind Sciences journal at Korea Advanced Institute of Science and Technology (KAIST), suggests that the youth can make a meaningful contribution to science policy through their passion and fresh perspectives.

Besides growing as a journal, MIT SPR has also grown as an organization in the past year. We invited the winners of the MIT Policy Hackathon 2020, a science policy competition

\footnotetext{
${ }^{1}$ Department of Chemistry, Massachusetts Institute of Technology, Cambridge, MA

*Email: ypetri@mit.edu
}

The authors declare no conflict of interest.

(C) 2021 The Author(s) organized by the MIT Technology and Policy Program (TPP), to submit articles to our journal. These initiatives resulted in several wonderful case studies and a review on halting COVID-19 transmission in prisons. Finally, we held two seminars for members of MIT SPR and the broader MIT community, where authors presented the research they have conducted while writing for our journal.

My vision is that MIT SPR will continue increasing its readership in the next decade and ultimately become a powerful brewing pot of creative ideas that stimulates engaging conversations between scientists, policymakers, and the public. I hope that such communication will bring about tangible positive change that is reflected on a state or federal level. With that, we are excited to introduce you to Volume II of MIT SPR!

\section{Acknowledgements}

I am grateful to Grant A. Knappe and Friederike M. C. Benning for their unrelenting support and guidance during my time as Editor-in-Chief. I would also like to thank the talented MIT SPR leadership team as well as our writers and Associate Editors for making this volume possible.

\section{Citation}

Petri, Y. MIT SPR spreads its wings in Volume II. MIT Science Policy Review 2, 1 (2021). https: //doi.org/10.38105/ spr. $53 \mathrm{ck} 4$ matk 7 .

\section{Open Access}

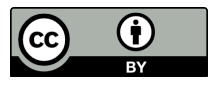

This MIT Science Policy Review article is licensed under a Creative Commons Attribution 4.0 International License, which permits use, sharing, adaptation, distribution and reproduction in any medium or format, as long as you give appropriate credit to the original author(s) and the source, provide a link to the Creative Commons license, and indicate if changes were made. The images or other third party material in this article are included in the article's Creative Commons license, unless indicated otherwise in a credit line to the material. If material is not included in the article's Creative Commons license and your intended use is not permitted by statutory regulation or exceeds the permitted use, you will need to obtain permission directly from the copyright holder. To view a copy of this license, visit http://creativecommons.org/licenses/ by $/ 4.0 /$. 